\title{
Scale insects (Hemiptera: Coccoidea) associated with arabica coffee and geographical distribution in the neotropical region
}

\author{
MAURÍCIO J. FORNAZIER ${ }^{1}$, DAVID S. MARTINS ${ }^{1}$, MARIA CRISTINA G. DE WILLINK ${ }^{2}$, \\ VICTOR D. PIROVANI ${ }^{3}$, PAULO S.F. FERREIRA ${ }^{4}$ and JOSÉ C. ZANUNCIO ${ }^{4}$

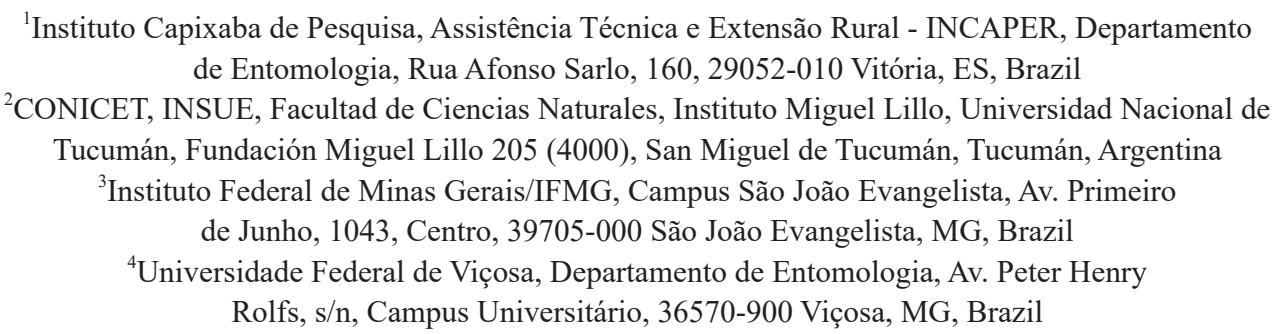

Manuscript received on October 7, 2016; accepted for publication on September 1, 2017

\begin{abstract}
Coffee is one of the most important Brazilian agricultural commodities exported, and Minas Gerais and Espírito Santo States are the main coffee producers. Scale insects are important coffee pests, and 73 species of Cerococcidae (3), Coccidae (18), Diaspididae (6), Eriococcidae (1), Ortheziidae (3), Pseudococcidae (21), Putoidae (2) and Rhizoecidae (19) have been associated with roots, branches, leaves, flowers and fruits of Arabica coffee in the Neotropics. Eight species were found associated with Arabica coffee in Minas Gerais and Espírito Santo States in this study, and Coccidae was the most frequent family. Coccus alpinus, Cc. celatus, Cc. lizeri, Cc. viridis, and Saissetia coffeae (Coccidae) were found in both states; Alecanochiton marquesi, Pseudaonidia trilobitiformis (Diaspididae), and Dysmicoccus texensis (Pseudococcidae) were only found in Minas Gerais. Alecanochiton marquesi and P. trilobitiformis are first reported in Minas Gerais, and Cc. alpinus in Espírito Santo, on Arabica coffee. All scale insect species were associated with coffee leaves and branches, except $D$. texensis, associated with coffee roots. Fourty seven scale insect species have been found occurring in Brazilian Arabica coffee, and in Espírito Santo (28) and Minas Gerais (23). Widespread and geographical distribution of each species found are discussed.
\end{abstract}

Key words: Coccidae, Coffea arabica, Diaspididae, geographical distribution, Pseudococcidae.

\section{INTRODUCTION}

Coffee is one of the most important Brazilian agricultural commodities exported, and $80 \%$ of this coffee is produced in Minas Gerais and Espírito

Correspondence to: Maurício José Fornazier

E-mail: mauriciofornazier@gmail.com
Santo States. Both coffee species, Coffea arabica L. (Arabica coffee) and Co. canephora Pierre ex A. Froehner (Robusta coffee) have been cultivated in Brazil, and first former accounts for $\sim 75 \%$ of the total production (IBGE 2015). Insects may reduce coffee yield, and scale insects (Hemiptera: Coccoidea) play an important role as pest associated 
with roots, branches, leaves, flowers and fruits of Arabica coffee in the Neotropics. The economic level of damage depends on climatic conditions, costs of production and prices in the international market (Fornazier et al. 2007).

Scale insects are major agricultural pests, particularly when they develop in new regions of coffee plantations free from their natural enemies (Culik et al. 2011). They have the habit of sucking the sap on leaves, stems, and roots, are polyphagous and attack a large number of agricultural and ornamental plantations (Miller et al. 2005, García Morales et al. 2016). These are insects of quarantine importance affecting the domestic and export market, causing damage to plants mainly by injecting toxins and transmitting pathogens such as viruses (Martins et al. 2004, Culik et al. 2006). The feeding behavior of scale insects affect negatively plant healthy or weakens plants, and may reduce plant vigor, causes premature defoliation, impact formation of new shoots, can lead to branch dieback, and eventually plant death. In addition, the honeydew excreted by scales allows the development of sooty mold that inhibits photosynthesis and causes cosmetic damage to fruits (Mibey 1997, Vandenberg et al. 2007). Also, it attracts ants and creats a mutual interaction between ants and scale insects as protective benefit to the scale insect against predators (Davidson et al. 2003, Hunt 2003, Bluthgen et al. 2004, Livingston et al. 2008, Shalene et al. 2009). Particularly young plants of coffee may be affected under field conditions, and depending on the scale insect species, age of the plantation, and infestation level, the replanting or total replacement of seedlings in the area may be required. They can also infest sprouts of seedlings in nurseries, and be disseminated to new plantations (Bittenbender 2000, Fernandes et al. 2009, Reis et al. 2010).

Worldwide 114 species of scale insects (Hemiptera: Coccoidea) have been cited in Arabica coffee, and 73 species Cerococcidae (3),
Coccidae (18), Diaspididae (6), Eriococcidae (1), Ortheziidae (3), Pseudococcidae (21), Putoidae (2) and Rhizoecidae (19) have been associated with roots, branches, leaves, flowers and fruits of Arabica coffee in the Neotropics. Fourty seven scale insect species have been found occurring in Brazilian Arabica coffee (García Morales et al. 2016). Coccidae (soft scales), Diaspididae (armored scales) and Pseudococcidae (mealybugs) are widespread throughout the world as pests on agricultural plantations and ornamental plants (Williams and Granara de Willink 1992, Henderson and Hodgson 2005). This research aimed to verify the geographical distribution of scale species (Hemiptera: Coccoidea) associated with Arabica coffee in the two main Brazilian states coffee producers, Espírito Santo and Minas Gerais, report those species associated with this coffee species, and their range expansion in the Neotropics.

\section{MATERIALS AND METHODS}

Scale insects were sampled from Arabica coffee commercial producing plantations with no chemical spraying at altitudes between 209 to 1,050 $\mathrm{m}$ in Minas Gerais and Espírito Santo States. Samplings were carried out in the municipalities of Cachoeirinha, Campos Altos, Ervália, Florestal, Itabira, Manhuaçu, Muriaé and Viçosa, Minas Gerais State, and in the municipalities of Domingos Martins, Ibatiba, Ibitirama, Iúna and Venda Nova do Imigrante, Espírito Santo State. Scale insects were collected manually from the leaves, branches, trunk, roots, and fruits. The canopies and roots of ten coffee plants were examined in each coffee orchard sampled for the presence of scale insects. Branch and trunk bark, and leaves infested with scale insects were collected, cut into $2 \times 2 \mathrm{~cm}$ pieces; infested rosettes and fruits were collected; the main and secondary roots of the coffee tree were sampled by digging a $20 \mathrm{~cm}$ diameter hole by $20 \mathrm{~cm}$ deep. The specimens collected were 
prepared and assembled on slides for microscopy (Granara de Willink 1990). This method consists on clarification using Essig solution composed of 20 parts of lactic acid (85\%), two parts of saturated phenol, four parts of glacial acetic acid and one part of distilled water; coloration was performed with fuchsin acid, dehydration with different concentrations of alcohol, and they were assembled in Canada balsam. Scale insects were identified in the Facultad de Ciencias Naturales e Instituto Miguel Lillo, Universidad Nacional de Tucumán, Argentina. Voucher specimens were deposited in the Regional Museum of Entomology, Department of Entomology, Universidade Federal de Viçosa (UFV) in Viçosa, Minas Gerais State, Brazil.

\section{RESULTS AND DISCUSSION}

In total, eight species were found associated with Arabica coffee in Minas Gerais and Espírito Santo States. Coccus alpinus De Lotto, 1960, Cc. celatus De Lotto, 1960, Cc. lizeri (Fonseca, 1957), Cc. viridis (Green, 1889), and Saissetia coffeae (Walker, 1852) (Coccidae) were found associated with Arabica coffee in the two main Brazilian states coffee producers, Espírito Santo and Minas Gerais; Alecanochiton marquesi Hempel, 1921 (Coccidae), Pseudaonidia trilobitiformis (Green, 1896) (Diaspididae), and Dysmicoccus texensis (Tinsley, 1900) (Pseudococcidae) were only found in Minas Gerais, Brazil. Alecanochiton marquesi and $P$. trilobitiformis are first reported occurring in Minas Gerais, and Cc. alpinus on Arabica coffee in Espírito Santo (Table I). All scale insect species were associated with coffee leaves and branches, except $D$. texensis, associated with coffee roots. Fourty seven scale insect species have been found occurring in Brazilian Arabica coffee, and in Espírito Santo (28) and Minas Gerais (23).

In the Neotropics, 73 scale species have been found associated with Arabica coffee. The largest number of species associated with coffee in the Neotropics, and found in Brazil belongs to Pseudococcidae (21), Coccidae (18) and Rhizoecidae (19). Cerococcidae has only three species occurring in the Neotropics, and two of them occur in Brazil; Putoidea was not recorded occurring in Brazilian Arabica coffee, but two scale species of this family have been associated with this crop in the Neotropics. From those 19 species of Rhizoecidae, four of them have been related in Brazilian Arabica coffee. The genera with the larger number of species associated with Arabica coffee in the Neotropics are Rhizoecus (11 species), Coccus (7), Dysmicoccus (6), and Pseudococcus (6); in Brazil, they are Coccus (7), Pseudococcus (6) and Dysmicoccus (5) (Table SI - Supplementary Material).

Coccus alpinus De Lotto, 1960, Cc. celatus De Lotto, 1960, Cc. lizeri (Fonseca, 1957), Cc. viridis (Green, 1889), and Saissetia coffeae (Walker, 1852) (Coccidae) were found associated with Arabica coffee in the two main Brazilian states coffee producers, Espírito Santo and Minas Gerais; Alecanochiton marquesi Hempel, 1921 (Coccidae), Pseudaonidia trilobitiformis (Green, 1896) (Diaspididae), and Dysmicoccus texensis (Tinsley, 1900) (Pseudococcidae) were only found in Minas Gerais, Brazil (Table I). Coccidae showed the highest diversity (75\%), and frequency ( $~ 87 \%)$. Cerococcus parahybensis Hempe1, 1927, Cc. alpinus De Lotto, 1960, Cc. brasiliensis Fonseca, 1957, Cc. celatus De Lotto, 1960, Cc. lizeri (Fonseca, 1957), Eriococcus coffeae (Hempel, 1919), Nipaecoccus coffeae (Hempel, 1919) have only been reported in Brazilian coffee plantations (Table SI). Most scale insects sampled came from coffee plantations abandoned by the farmers. This fact probably has resulted in the increase of scale insects by the lack of chemical control in these abandoned crops, and the absence of efficient natural enemies.

Alecanochiton marquesi is first reported occurring in Minas Gerais State (209 m), Brazil, 
TABLE I

Families and scale insect species (Hemiptera: Coccoidea) collected in Coffea arabica L., and respective municipalities, elevations (Elv), latitude (Lat), and longitude (Long), States of Espírito Santo (ES) and Minas Gerais (MG), Brazil, 2014.

\begin{tabular}{|c|c|c|c|c|c|c|}
\hline Family/species & Municipalities & State & Stratum & $\begin{array}{l}\text { Elv } \\
(\mathrm{m})\end{array}$ & $\begin{array}{l}\text { Lat } \\
\text { (S) }\end{array}$ & $\begin{array}{l}\text { Long } \\
(\mathrm{W})\end{array}$ \\
\hline \multicolumn{7}{|l|}{ COCCIDAE } \\
\hline \multirow{4}{*}{$\begin{array}{l}\text { Alecanochiton } \\
\text { marquesi } \\
\text { Coccus alpinus }\end{array}$} & Muriaé & MG & branches & 209 & $21^{\circ} 07^{\prime} 50^{\prime \prime}$ & $42^{\circ} 21^{\prime} 59^{\prime \prime}$ \\
\hline & Itabira & $\mathrm{MG}$ & leaves. branches & 779 & $19^{\circ} 37^{\prime} 09^{\prime \prime}$ & $43^{\circ} 13^{\prime} 37^{\prime \prime}$ \\
\hline & Viçosa & $\mathrm{MG}$ & leaves. shoots & 648 & $20^{\circ} 45^{\prime} 14^{\prime \prime}$ & $42^{\circ} 52^{\prime} 55^{\prime \prime}$ \\
\hline & $\begin{array}{l}\text { Venda Nova do } \\
\text { Imigrante }\end{array}$ & ES & leaves. branches & 630 & $20^{\circ} 20^{\prime} 23^{\prime \prime}$ & $41^{\circ} 08^{\prime} 05^{\prime \prime}$ \\
\hline \multirow[t]{6}{*}{ Coccus celatus } & Campos Altos & MG & branches & 1.050 & $19^{\circ} 41^{\prime} 46^{\prime \prime}$ & $46^{\circ} 10^{\prime} 17^{\prime \prime}$ \\
\hline & Manhuaçu & $\mathrm{MG}$ & leaves. branches & 635 & $20^{\circ} 15^{\prime} 29^{\prime \prime}$ & $42^{\circ} 02^{\prime} 03^{\prime \prime}$ \\
\hline & Muriaé & $\mathrm{MG}$ & leaves. branches & 209 & $21^{\circ} 07^{\prime} 50^{\prime \prime}$ & $42^{\circ} 21^{\prime} 59^{\prime \prime}$ \\
\hline & Ibatiba & ES & leaves. branches & 740 & $20^{\circ} 15^{\prime} 00^{\prime \prime}$ & $41^{\circ} 31^{\prime} 00^{\prime \prime}$ \\
\hline & Ibitirama & ES & leaves. branches & 765 & $20^{\circ} 32^{\prime} 00^{\prime \prime}$ & $41^{\circ} 40^{\prime} 00^{\prime \prime}$ \\
\hline & Iúna & ES & leaves. branches & 650 & $20^{\circ} 22^{\prime} 00^{\prime \prime}$ & $41^{\circ} 32^{\prime} 00^{\prime \prime}$ \\
\hline \multirow[t]{6}{*}{ Coccus lizeri } & Cachoeirinha & $\mathrm{MG}$ & leaves & 739 & $20^{\circ} 44^{\prime} 10^{\prime \prime}$ & $42^{\circ} 46^{\prime} 26^{\prime \prime}$ \\
\hline & Campos Altos & MG & leaves & 1.050 & $19^{\circ} 41^{\prime} 46^{\prime \prime}$ & $46^{\circ} 10^{\prime} 17^{\prime \prime}$ \\
\hline & Florestal & MG & leaves & 779 & $19^{\circ} 53^{\prime} 22^{\prime \prime}$ & $44^{\circ} 25^{\prime} 57^{\prime \prime}$ \\
\hline & Muriaé & MG & leaves & 209 & $21^{\circ} 07^{\prime} 50^{\prime \prime}$ & $42^{\circ} 21^{\prime} 59^{\prime \prime}$ \\
\hline & Domingos Martins & ES & leaves & 620 & $20^{\circ} 21^{\prime} 48^{\prime \prime}$ & $40^{\circ} 39^{\prime} 33^{\prime \prime}$ \\
\hline & $\begin{array}{l}\text { Venda Nova do } \\
\text { Imigrante }\end{array}$ & ES & leaves & 630 & $20^{\circ} 20^{\prime} 23^{\prime \prime}$ & $41^{\circ} 08^{\prime} 05^{\prime \prime}$ \\
\hline \multirow[t]{2}{*}{ Coccus viridis } & Campos Altos & MG & $\begin{array}{l}\text { leaves. shoots, } \\
\text { rosettes }\end{array}$ & 1.050 & $19^{\circ} 41^{\prime} 46^{\prime \prime}$ & $46^{\circ} 10^{\prime} 17^{\prime \prime}$ \\
\hline & Iúna & ES & leaves. shoots & 650 & $20^{\circ} 22^{\prime} 00^{\prime \prime}$ & $41^{\circ} 32^{\prime} 00^{\prime \prime}$ \\
\hline \multirow[t]{2}{*}{ Saissetia coffeae } & Campos Altos & MG & leaves. branches & 1.050 & $19^{\circ} 41^{\prime} 46^{\prime \prime}$ & $46^{\circ} 10^{\prime} 17^{\prime \prime}$ \\
\hline & Ibatiba & ES & leaves. branches & 740 & $20^{\circ} 15^{\prime} 00^{\prime \prime}$ & $41^{\circ} 31^{\prime} 00^{\prime \prime}$ \\
\hline \multicolumn{7}{|l|}{ DIASPIDIDAE } \\
\hline \multirow[t]{2}{*}{$\begin{array}{l}\text { Pseudaonidia } \\
\text { trilobitiformis }\end{array}$} & Campos Altos & MG & leaves. branches & 1.050 & $19^{\circ} 41^{\prime} 46^{\prime \prime}$ & $46^{\circ} 10^{\prime} 17^{\prime \prime}$ \\
\hline & Ervália & $\mathrm{MG}$ & leaves & 780 & $20^{\circ} 50^{\prime} 24^{\prime \prime}$ & $42^{\circ} 39^{\prime} 26^{\prime \prime}$ \\
\hline \multicolumn{7}{|c|}{ PSEUDOCOCCIDAE } \\
\hline $\begin{array}{l}\text { Dysmicoccus } \\
\text { texensis }\end{array}$ & Manhuaçu & $\mathrm{MG}$ & roots & 635 & $20^{\circ} 15^{\prime} 29^{\prime \prime}$ & $42^{\circ} 02^{\prime} 03^{\prime \prime}$ \\
\hline
\end{tabular}


and it has been recorded in the Neotropical region, including French Guiana. In Brazil, this species was first recorded in the municipality of Angatuba, São Paulo State on Coffea sp. (Hempel 1921, Silva et al. 1968), and it has also been reported in the States of Paraíba, Pernambuco, Rio de Janeiro, and Santa Catarina, but not associated with coffee. This species has few hosts, such as Coffea spp., Gonzalagunia spicata, Ixora spp. (Rubiaceae), Chrysophyllum caimito (Sapotaceae), Gossypium spp. (Malvaceae), Jasminum spp. (Oleaceae), Melaleuca spp. (Myrtaceae), and Lacuma caimito (Sapotaceae) (Silva et al. 1968, Hodgson 1994, Jenkins 2015, García Morales et al. 2016).

The genus Coccus has about 90 widely distributed species in all zoogeographical regions. Some species of this genus are pests in horticultural and ornamental plants (Hodgson 1994, Williams and Ben-Dov 2009, Martin and Lau 2011, Wang and Feng 2012). It is the second most common genus of this scale insect family, and all species of this genus associated with Arabica coffee have been found in Brazil (Table SI).

The new finding of Cc. alpinus represents the range expansion of its geographical distribution in Minas Gerais State, and its first report in Arabica coffee in Espírito Santo State (Table I). This scale species was related to the Afrotropical and Neotropical regions, and its host plants include species of Apocynaceae, Celastraceae, Ehretiaceae, Myrtaceae, Rubiaceae, Rutaceae, and Theaceae (García Morales et al. 2016). This coccid was found in Malawi in Arabica coffee above 1,220 m (Murphy 1991), in Papua New Guinea (Hillocks et al. 1999), and on coffee plants in the Brazilian States of Bahia, and Minas Gerais (Granara de Willink et al. 2010, García Morales et al. 2016). This species remains restrict to Brazilian Arabica coffee in the Neotropics (Table SI).

Coccus celatus was found in Arabica coffee in Espírito Santo and Minas Gerais States which represents its range expansion at different elevations from $209 \mathrm{~m}$ to $1,050 \mathrm{~m}$ (Table I). This soft scale is distributed in the Afrotropical, Australasian, Neotropical, and Oriental regions. Its host plants belong to Annonaceae, Apocynaceae, Calophyllaceae, Casuarinaceae, Clusiaceae, Costaceae, Euphorbiaceae, Fabaceae, Myrtaceae, Rubiaceae, and Rutaceae (García Morales et al. 2016). This species had been one of the main pests of Arabica coffee in highland above 1,000 $\mathrm{m}$ in Papua New Guinea for several decades (Murphy 1991). This species was first reported associated with Arabica coffee in Brazil by Granara de Willink et al. (2010) (Table SI).

A range expansion of the geographical distribution of Cc. lizeri in Arabica coffee was observed to the municipality of Campos Altos $(1,200 \mathrm{~m})$, Minas Gerais State (Table I). This species had been reported on Coffea spp. in São Paulo State, Brazil (Fonseca 1957, García Morales et al. 2016), and altitude seems not bring any influence on this species distribution. It has been associated with Arabica coffee in the Brazilian states of Bahia, Espírito Santo, Minas Gerais, and São Paulo (Table SI), and hitherto it remains restrict to these Brazilian states (Granara de Willink et al. 2010).

Coccus viridis associated with Arabica coffee was found in the municipalities of Campos Altos, Minas Gerais, and Iuna, Espírito Santo (Table I) representing a range expansion of the geographical distribution of this green coffee scale in Brazil. The species was found only at high altitudes above 1,000 $\mathrm{m}$. This is a generalist and invasive pest species spread on tropical and subtropical regions under anthropogenic activities (Wyckhuys et al. 2013); it is reported in many countries in the Neotropics, including Brazil (Granara de Willink et al. 2010, García Morales et al. 2016) where it has been related occurring in several hosts in the States of Bahia, Espírito Santo, Minas Gerais, Pará, Paraná, Rio de Janeiro, Rio Grande do Norte, Rio Grande do Sul, Santa Catarina and São Paulo (Table SI). 
Coccus viridis has a great capacity for colonization and adaptation in new areas that may be attributed to their habits of polyphagy and parthenogenetic reproduction (Malumphy and Treseder 2012). Their worldwide hosts include 61 families of plants, and this species has been considered as an important fruit and indoor plant pest in temperate regions (Poole 2005, Waite et al. 2012, Malumphy and Treseder 2012, García Morales et al. 2016). This coffee scale is associated with Co. arabica, Co. canephora, Co. liberica, and Co. robusta (García Morales et al. 2016), and these associations occur mostly in young host plants (Dekle and Fasulo 2009, Fernandes et al. 2009). The green coffee scale was considered as the largest Arabica coffee pest in highland areas $(>1,000 \mathrm{~m})$, and it may causes losses in the harvest (Murphy 1991). However, it was regarded as an ocasional pest in organic coffee (Vandermeer et al. 2010). Coffee plants infested by Cc. viridis have their growth delayed and may even die (Bittenbender 2000, Fernandes et al. 2009).

The new finding of $S$. coffeae in Arabica coffee in the States of Minas Gerais and Espírito Santo (Table I) is an increase range of the species. It is considered cosmopolitan, and found in Afrotropical, Australian, Neartic, Neotropical, Oriental, and Palaearctic regions. This scale insect has been found in the Neotropics in near countries of Brazil such as Argentina, Chile, Colombia, French Guiana, Guiana, and Peru. It has been reported in the Brazilian states of Amazonas, Alagoas, Bahia, Espírito Santo, Minas Gerais, Pará, Paraíba, Paraná, Rio de Janeiro, Rio Grande do Sul, and São Paulo (Table SI). Saissetia spp. (Hemiptera: Coccidae) may cause losses of vigor, spots on the foliage, deformation of plant parts, retard plant growth, and premature death of infested parts (Valand et al. 1989). This is a polyphagous scale species and an important pest of fruit trees and ornamental plants (Peronti et al. 2001, Badary 2010). Important commodity plantations in Brazil such as Co. arabica, Co. canephora (Rubiaceae),
Citrus aurantium, Ci. aurantifolia, Ci. limon, Ci. reticulata, and $C i$. sinensis (Rutaceae) may be damaged by S. coffeae (De Lotto 1956, Ben-Dov 1971, Nakahara 1983, Hamon and Williams 1984, González and Lamborot 1989, Shafee et al. 1989, Williams and Watson 1990, Henderson et al. 2010, García Morales et al. 2016).

Pseudaonidia trilobitiformis (Hemiptera: Diaspididae) is first reported occurring in Arabica coffee in Minas Gerais, found in the municipalities of Campos Altos and Ervália (Table I). This species has been worldwide reported on 178 plant species of 45 families (Wolff and Corseuil 1993, Claps et al. 2001, Peronti et al. 2001, Raga et al. 2003, García Morales et al. 2016). In the Neotropics it has been found in Argentina, Bahamas, Bolivia, Brazil, Colombia, Costa Rica, Ecuador, El Salvador, French Guiana, Galapagos Island, Guadeloupe, Guatemala, Guyana, Haiti, Martinique, Panama, Peru, Puerto Rico \& Vieques Island, Saint Martin \& St. Barthelemy, Suriname, and Tobago, U.S. Virgin Islands, Uruguay, and Venezuela (Wolff and Corseuil 1993, Kondo 2001, Vasquez et al. 2002, Perez-Gelabert 2008, García Morales et al. 2016). It was recorded in the Brazilian states of Bahia, Ceará, Espírito Santo, Minas Gerais, Pará, Paraíba, Paraná, Pernambuco, Rio de Janeiro, Rio Grande do Norte, Rio Grande do Sul, and São Paulo (Table SI). This species may be found in Co. canephora, Ixora coccinea (Rubiaceae), Laurus nobilis (Lauraceae), Murraya paniculata (Myrtaceae), and Nerium oleander (Apocynaceae) in Espírito Santo State (Culik et al. 2008), but not in Arabica coffee. Diaspididae can be considered as a cosmopolitan pest of quarantine importance by the large number of host plants, particularly perennial crops (Miller et al. 2005).

Dysmicoccus texensis was found in the municipality of Manhuaçu, Minas Gerais State (Table I). This is a common species in Colombia coffee plantations (Kondo et al. 2008), and it has been reported in Mexico, and Texas in the USA 
(Nearctic region), Argentina, Bahamas, Belize, Brazil, Colombia, Costa Rica, Cuba, Dominican Republic, Ecuador, El Salvador, Guadeloupe, Guatemala, Haiti, Jamaica, Mexico, Peru, Puerto Rico \& Vieques Island, Trinidad and Tobago, Uruguay, and U.S. Virgin Islands in the Neotropics (Table SI). García Morales et al. (2016), apud Santa-Cecília et al. (2002a) related its occurrence in the Brazilian States of São Paulo (Nakano 1972), Espírito Santo, and Minas Gerais. However, these authors wrote: "Root coffee (Co. arabica) mealybugs (Hemiptera: Pseudococcidae) collected in Boa Esperança, southern Minas Gerais State, were identified as Dysmicoccus texensis (Tinsley) (=bispinosus Beardsley) and those from aerial part collected in Castelo, Espírito Santo State, as Planococcus minor (Maskell)". The authors did not reported D. texensis occurring in Arabica coffee in Espírito Santo State; thus, the association of $D$. texensis with Arabica coffee must be considered restricted to the Brazilian States of São Paulo and Minas Gerais. This species was reported in Espírito Santo State infesting Ananas comosus, Cucurbita pepo, Cocos nucifera, Annona sp., and Co. canephora (Culik et al. 2011). This species occurs on Arabica coffee plantations in several municipalities of São Paulo State and southern Minas Gerais (Nakano 1972), and may infest fruits, roots, and twigs (Santa-Cecília et al. 2002a, Kondo et al. 2008). Its host plants includes 36 plant species of Anacardiaceae, Araceae, Bignoniaceae, Bromeliaceae, Calophyllaceae, Clusiaceae, Cyperaceae, Euphorbiaceae, Fabaceae, Lauraceae, Malvaceae (including Sterculiaceae), Meliaceae, Musaceae, Myrtaceae, Polygonaceae, Rubiaceae, Rutaceae, Solanaceae (Granara de Willink 2009, García Morales et al. 2016). This is a scale species that has occasionally been found on coffee plants (Souza et al. 2008). Dactylopius texensis Tinsley, 1900, Dysmicoccus bispinosus Beardsley, 1965, and Pseudococcus texensis Fernald, 1903 are considered junior synonymous (Granara de Willink 2009, García Morales et al. 2016).

Scale insects associated with Arabica coffee showed the diversity of this group in Brazil and the wide range expansion of several of these species. Most Rhizoecidae scale species associated with Arabica coffee in the Neotropical region are not reported occurring in Brazilian Arabica coffee, and it is important because if introduced they may be established in Brazil. Alecanochiton marquesi and $P$. trilobitiformis are first reported associated with Arabica coffee in Minas Gerais, and $C c$. alpinus in Espírito Santo. Dismycoccus texensis remains restricted to Minas Gerais and São Paulo in Arabic coffee. The periods of low coffee prices in international market may influence the spread of scale insect species due to the reduced pest control by Brazilian coffee producers. Elevations, in general, did not seem to influence the spread of scale insect species found on samples. Information obtained in this study are of interest to Brazilian coffee producers, and to other regions. It will help to improve the knowledge of geographical distribution, and spread of scale insects associated with Arabica coffee in the Neotropics, particularly in Brazil.

\section{ACKNOWLEDGMENTS}

We thank the Conselho Nacional de Desenvolvimento Científico e Tecnológico (CNPq), Fundação de Amparo à Pesquisa e Inovação do Espírito Santo (FAPES), Fundação de Amparo à Pesquisa do Estado de Minas Gerais (FAPEMIG), Financiadora de Estudos e Projetos (FINEP) from Brazil, Consejo Nacional de Investigaciones Científicas y Técnicas (CONICET) and Instituto Superior de Entomología (INSUE) from Argentina.

\section{REFERENCES}

ALVES VS, MOINO JUNIOR A, SANTA-CECÍLIA LVC, ROHDE C AND SILVA MAT. 2009. Testes em 
condições para o controle de Dysmicoccus texensis (Tinsley) (Hemiptera, Pseudococcidae) em cafeeiro com nematoides entomopatogênicos do gênero Heterorhabditis (Rhabditida, Heterorhabditidae). Rev Bras Entomol 53: 139-143.

BADARY H. 2010. Ecological aspects of Sassetia spp. (Coccidae: Coccoidae: Hemiptera) and their natural enemies in Egypt. Egypt Acad J Biolog Sci 4: 163-174.

BEN-DOV Y. 1971. An annotated list of the soft scale insects (Homoptera: Coccidae) of Israel. Isr J Entomol 6: 23-34.

BITTENBENDER HC. 2000. Plantation profile for coffee in Hawaii. http://www.ipmcenters.org/plantationprofiles/ docs/hicoffee.html/. Accessed June 20, 2015.

BLUTHGEN N, STORK NE AND FIEDLER K. 2004. Bottom-up control and co-occurrence in complex communities: honeydew and nectar determine a rainforest ant mosaic. Oikos 106: 344-358.

CLAPS LE, WOLFF VRS AND GONZÁLEZ RH. 2001. Catálogo de las Diaspididae (Hemiptera: Coccoidea) exóticas de la Argentina, Brasil y Chile. Rev Soc Entomol Argent 60: 9-34.

CORSEUIL E AND BARBOSA VMB. 1971. A família Coccidae no Rio Grande do Sul (Homoptera: Coccoidea). Arq Mus Nac 54: 237-241.

CULIK MP, FORNAZIER MJ, MARTINS DS, ZANUNCIO JUNIOR JS, VENTURA JA, PERONTI ALBG AND ZANUNCIO JC. 2013b. The invasive mealybug Maconellicoccus hirsutus: lessons for its current range expansion in South America and invasive pest management in general. J Pest Sci 86: 387-398.

CULIK MP, MARTINS DS AND GULLAN PJ. 2006. First records of two mealybug species in Brazil and new potential pests of papaya and coffee. J Insect Sci 6: 6 . http://insectscience.org/6.23. Accessed June 20, 2015.

CULIK MP, MARTINS DS, VENTURA JA, PERONTI ALBG, GULLAN PJ AND KONDO T. 2007. Coccidae, Pseudococcidae, Ortheziidae, and Monophlebidae (Hemiptera: Coccoidea) of Espírito Santo, Brazil. Biota Neotrop 7: 61-65.

CULIK MP, MARTINS DS, VENTURA JA AND WOLFF VS. 2008. Diaspididae (Hemiptera: Coccoidea) of Espírito Santo, Brazil. J Insect Sci 8: 6. http://insectscience. org/8.17/. Accessed June 20, 2015.

CULIK MP, MARTINS DS, ZANUNCIO JUNIOR JS, FORNAZIER MJ, VENTURA JA, PERONTI ALBG AND ZANUNCIO JC. 2013a. The invasive hibiscus mealybug Maconellicoccus hirsutus (Hemiptera: Pseudococcidae) and its recent range expansion in Brazil. Fla Entomol 96: 638-640.

CULIK MP, VENTURA JA AND MARTINS DS. 2009. Scale insects (Hemiptera: Coccoidea) of pineapple in the State of Espírito Santo, Brazil. Acta Hortic 822: 215-218.
CULIK MP, WOLF VRS, PERONTI ALBG, BEN-DOV Y AND VENTURA JA. 2011. Hemiptera, Coccoidea: Distribution extension and new records for the states of Espírito Santo, Ceará, and Pernambuco, Brazil. Check List 7: $567-570$.

DAVIDSON DW, COOK SC, SNELLING R AND CHUA TH. 2003. Explaining the abundance of ants in lowland tropical rainforest canopies. Science 300: 969-972.

DE LOTTO G. 1956. The identity of some East African species of Saissetia (Homoptera, Coccidae). B Entomol Res 47: 239-249.

DEKLE GW AND FASULO TT. 2009. Green scale, Coccus viridis (Green) (Insecta: Hemiptera: Coccidae). Featured creatures. University of Florida's Institute of Food and Agricultural Sciences. http://entnemdept.ufl.edu/creatures/ orn/scales/green_scale.htm/. Accessed June 18, 2014.

FERNANDES FL, PICANÇO MC, FERNANDES ME, GALDINO TV AND TOMAZ AC. 2009. Perdas causadas por Coccus viridis (Green) (Hemiptera: Coccidae) em mudas de Coffea arabica L. EntomoBrasilis 2: 49-53.

FONSECA JP. 1957. Três novas espécies de coccídeos do Brasil, sobre cafeeiro (Homoptera: Coccidae). Arq Inst Biol 24: 123-135.

FORNAZIER MJ, FANTON CJ, BENASSI VLMR AND MARTINS DS. 2007. Pragas do café conilon. In: Ferrão RG, Fonseca AFA, Bragança SM, Ferrão MAG and De Muner LH (Eds), Café conilon, $1^{\text {st }}$ ed., Vitória: Incaper, p. 405-449.

GARCÍA MORALES M, DENNO BD, MILLER DR, MILLER GL, BEN-DOV Y AND HARDY NB. 2016. ScaleNet: A literature-based model of scale insect biology and systematics. http://scalenet.info. Accessed September 30, 2016.

GONZÁLEZ RH AND LAMBOROT L. 1989. El genero Saissetia Deplanche en Chile (Homoptera: Coccidae). Acta Entomol Chil 15: 237-242.

GRANARA DE WILLINK MC. 1990. Conociendo nuestra fauna: I. Superfamilia Coccoiddea (Homoptera: Sternorrhyncha). Serie monográfica y didáctica n. 6, Universidad Nacional de Tucumán Facultad de Ciencias Naturales e Instituto Miguel Lillo: Argentina, 43 p.

GRANARA DE WILLINK MC. 2009. Dysmicoccus from the Neotropical Region (Hemiptera: Pseudococcidae). Rev Soc Entomol Argent 68: 11-95.

GRANARA DE WILLINK MC, PIROVANI VD AND FERREIRA PSF. 2010. Las especies de Coccus que afectan Coffea arabica en Brasil (Coccoidea: Coccidae) y redescripcion de dos especies. Neotrop Entomol 39: 391399.

HAMON AB AND WILLIAMS ML. 1984. The soft scale insects of Florida (Homoptera: Coccoidea: Coccidae). Arthropods of Florida and Neighboring Land Areas 11: $1-194$. 
HEMPEL A. 1921. Três novos coccídeos. Arch Esc Sup Agric Med Vet 5: 143-146.

HENDERSON RC AND HODGSON CJ. 2005. Two new species of Umbonichiton (Hemiptera: Sternorrhyncha: Coccoidea: Coccidae) from New Zealand. Zootaxa 854: $1-11$.

HENDERSON RC, SULTAN A AND ROBERTSON AW. 2010. Scale insect fauna (Hemiptera: Sternorrhyncha: Coccoidea) of New Zealand's pygmy mistletoes (Korthalsella: Viscaceae) with description of three new species: Leucaspis albotecta, L. trilobata (Diaspididae) and Eriococcus korthalsellae (Eriococcidae). Zootaxa 2644: 1-24.

HILLOCKS RJ, PHIRI NA AND OVER D. 1999. Coffee pest and disease management options for smallholders in Malawi. Plantation Prot 18: 199-206.

HODGSON CJ. 1994. The scale insect family Coccidae: an identification manual to genera. Wallingford: CAB International, $639 \mathrm{p}$.

HUNT JH. 2003. Cryptic herbivores of the rainforest canopy. Science 300: 916-917.

IBGE. 2015. Café. Levantamento sistemático da produção agrícola: novembro 2015. http://ftp.ibge.gov.br/Producao Agricola/Levantamento_Sistematico_da_Producao_ Agricola_[mensal]/Fasciculo/lspa_201511.pdf. Acessado em 20 de Junho, 2016.

JENKINS DA. 2015. Alechanochiton marquesi: a new scale species in Puerto Rico. http://entomologylabpr.blogspot. com.br/2013/03/alechanochiton-marquesi-new-scale. html/. Accessed June 13, 2016.

KONDO T. 2001. Las cochinillas de Colombia (Hemiptera: Coccoidea). Biota Colomb 2: 31-48.

KONDO T. 2013. A new species of Toumeyella Cockerell (Hemiptera: Coccoidea: Coccidae) on coffee roots, Coffea arabica L. (Rubiaceae), from Colombia and Venezuela. Corpoica Cienc Tecnol Agropecu 14: 39-51.

KONDO T, PORTILLA AAR AND NAVARRO EVV. 2008. Updated list of mealybugs and putoids from Colombia (Hemiptera: Psudococcidae and Putoidea). Bol Mus Entomol Univ Valle 9: 29-53.

LIVINGSTON GF, WHITE AM AND KRATZ CJ. 2008. Indirect interactions between ant-tended hemipterans, a dominant ant Azteca instabilis (Hymenoptera: Formicidae), and shade trees in a tropical agroecosystem. Environ Entomol 37: 734-740.

MALUMPHY C AND TRESEDER K. 2012. Green coffee scale Coccus viridis (Hemiptera: Coccidae), new to Britain. Brit J Entomol Nat Hist 25: 217-225.

MARTIN JH AND LAU CSK. 2011. The HemipteraSternorrhyncha (Insecta) of Hong Kong, China-an annotated inventory citing voucher specimens and published records. Zootaxa 2847: 1-122.
MARTINS DS, CULIK MP AND WOLFF VRS. 2004. New record of scale insects (Hemiptera: Coccoidea) as pests of papaya in Brazil. Neotrop Entomol 33: 655-657.

MIBEY RK. 1997. Sooty moulds. In: Ben-Dov Y and Hodgson CJ (Eds), Soft scale insects: Their biology, natural enemies and control, Amsterdam: Elsevier, p. 275-290.

MILLER DR, MILLER GL, HODGES GS AND DAVIDSON JA. 2005. Introduced scale insects (Hemiptera: Coccoidea) of the United States and their impact on U.S. agriculture. P Entomol Soc Wash 107: 123-158.

MURPHY ST. 1991. Insect natural enemies of coffee green scales (Hemiptera: Coccidae) in Kenya and their potential for biological control of Coccus celatus and C. viridis in Papua New Guinea. Entomophaga 36: 519-529.

NAKAHARA S. 1983. List of the Coccoidea species (Homoptera) of the United States Virgin Islands. United States Department of Agriculture, Plant Protection and Quarantine. APHIS 8142: 1-21.

NAKANO O. 1972. Estudo da cochonilha da raiz do cafeeiro, Dysmicoccus cryptus (Hempel, 1918) comb. n. (Homoptera: Pseudococcidae), PhD. Thesis. Escola Superior de Agricultura Luiz de Queiróz, Universidade de São Paulo. São Paulo, Brasil, 130 p.

PEREZ-GELABERT DE. 2008. Arthropods of Hispaniola (Dominican Republic and Haiti): a checklist and bibliography. Zootaxa 1831: 1-530.

PERONTI ALBG, MILLER DR AND SOUSA-SILVA CR. 2001. Scale insects (Hemiptera: Coccoidea) of ornamental plants from São Carlos, São Paulo, Brazil. Insecta Mundi 15: 247-255.

POOLE M. 2005. Green coffee scale Coccus viridis (Green) (Hemiptera: Coccidae). http://www.agric.wa.gov.au/ objtwr/imported_assets/content/pw/gcsfactsheet041109. pdf. Accessed April 20, 2016.

RAGA A, MINEIRO JLC AND WOLFF VRS. 2003. Novos registros de hospedeiros de cochonilhas (Hemiptera: Diaspididae, Coccidae) no Estado de São Paulo. Arq Inst Biol 70: 57-60.

REIS PR, SOUZA JC, SANTA-CECÍLIA LVC, SILVA RA AND ZACARIAS MS. 2010. Manejo integrado de pragas do cafeeiro. In: Reis PR and Cunha RL (Eds), Café arábica: do plantio à colheita. Lavras: Epamig 1: 573-688.

SANTA-CECÍLIA LVC, REIS PR AND SOUZA JC. 2002a. Sobre a nomenclatura das espécies de cochonilhasfarinhentas do cafeeiro nos Estados de Minas Gerais e Espírito Santo. Neotropi Entomol 31: 333-334.

SANTA-CECÍLIA LVC, SIMÕES JC AND SOUZA IF. 2002b. Dinâmica de populações e preferência alimentar da cochonilhada-raiz (Pseudococcus comstocki) pela tiririca. Planta Daninha 20: 39-43.

SANTA-CECÍLIA LVC AND SOUZA B. 2014. Cochonilhasfarinhentas de maior ocorrência em cafeeiros no Brasil. Informe Agropec 35: 45-54. 
SANTA-CECÍLIA LVC, SOUZA B, SOUZA JC, PRADO E, MOINO JR A, FORNAZIER MJ AND CARVALHO GA. 2007. Cochonilhas-farinhentas em cafeeiros: bioecologia, danos e métodos de controle. Belo Horizonte: Epamig, 48 p. (Epamig. Boletim Técnico, 79).

SHAFEE SA, YOUSUF M AND KHAN MY. 1989. Host plants and distribution of coccid pests (Homoptera: Coccoidea) in India. Indian J Syst Entomol 6: 47-55.

SHALENE JHA, VANDERMEER JH AND PERFECTO I. 2009. Population dynamics of Coccus viridis, a ubiquitous ant-tended agricultural pest, assessed by a new photographic method. B Insectol 62: 183-189.

SILVA AGA, GONÇALVES CR, GALVÃO DM, GONÇALVES AJL, GOMES J, SILVA MN AND SIMONI L. 1968. Quarto catálogo dos insetos que vivem nas plantas do Brasil seus parasitos e predadores. Parte II $1^{\circ}$ Tomo. Rio de Janeiro: Ministério da Agricultura, $622 \mathrm{p}$.

SOUZA B, SANTA-CECÍLIA LVC, PRADO E AND SOUZA JC. 2008. Cochonilhas farinhentas (Hemiptera: Pseudococcidae) em cafeeiros (Coffea arabica L.) em Minas Gerais. Coffee Sci 3: 104-107.

VALAND VM, PATEL JI AND MEHTA DM. 1989. Biology of brown scale (Saissetia coffeae) on pointed gourd (Trichosanthes dioica). Indian J Agricult Sci 59: 610-611.

VANDENBERG JD, SHELTON AM AND WRAIGHT SP. 2007. Application and evaluation of entomopathogens in crucifers and cucurbits. In: Lacey L and Kaya H (Eds), Field manual of techniques in invertebrate pathology, Dordrecht: Springer, p. 361-374.

VANDERMEER J, PERFECTO I AND PHILPOTT S. 2010. Ecological complexity and pest control in organic coffee production: uncovering an autonomous ecosystem service. BioScience 60: 527-537.

VASQUEZ J, DELGADO C, COUTURIER G AND MATILEFERRERO D. 2002. Harmful insects for the guava tree
(Psidium guajava L.: Myrtaceae) in Peruvian Amazonia. Fruits 57: 323-334.

WAITE G, ELDER R AND CARSON C. 2012. Green coffee scale on fruit trees and ornamental plants. http://www.daff. qld.gov.au/26_17184.htm/. Accessed June 18, 2015.

WANG F AND FENG JN. 2012. A new species of Coccus (Hemiptera, Coccoidea, Coccidae) from China. ZooKeys 244: 59-65.

WILLIAMS DJ AND BEN-DOV Y. 2009. A review of species names combined with the genus name Coccus Linnaeus (Hemiptera: Sternorrhyncha: Coccoidea). Zootaxa 2285: $1-64$.

WILLIAMS DJ AND GRANARA DE WILLINK MC. 1992. Mealybugs of Central and South America. London: CAB International, $635 \mathrm{p}$.

WILLIAMS DJ AND WATSON GW. 1990. The scale insects of the tropical south pacific region. Pt. 3: The soft scales (Coccidae) and other families. London: CAB International, $267 \mathrm{p}$.

WOLFF VRS AND CORSEUIL E. 1993. Espécies de Diaspididae (Hom.: Coccoidea) ocorrentes em plantas cítricas no Rio Grande do Sul, Brasil: I - Aspidiotinae. Biociências 1: 25-60.

WYCKHUYS KAG, KONDO T, HERRERA BV, MILLER DR, NARANJO N AND HYMAN G. 2013. Invasion of exotic arthropods in South America's biodiversity hotspots and agro-production systems. In: Peña JE (Ed), Potential Invasive Pests, Wallingford: CAB International, p. 373400 .

\section{SUPPLEMENTARY MATERIAL}

TABLE SI - Coccoidea (Hemiptera) recorded in Coffea arabica L., and geographical distribution in the Neotropical Region [based on García Morales et al. (2016), and additional references cited]. 